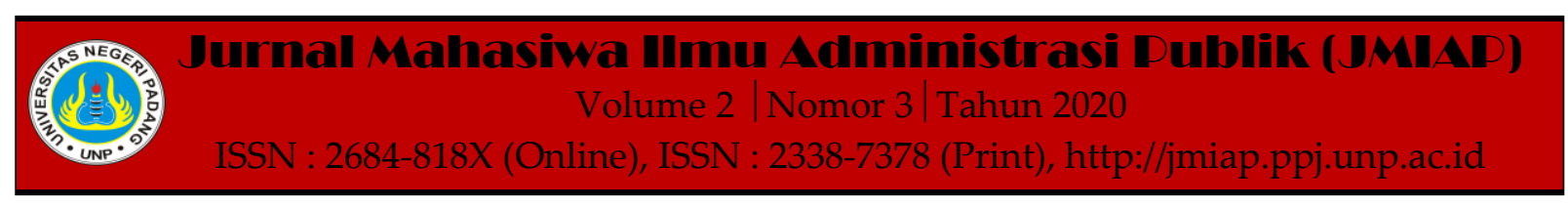

\title{
ANALISIS KESIAPSIAGAAN SISWA DALAM MENGHADAPI RISIKO BENCANA GEMPA BUMI DAN TSUNAMI
}

\author{
Kessy Deajeng Sudirman ${ }^{1(a)}$, Zikri Alhadi $^{2(b)}$ \\ ${ }^{1}$ Jurusan Ilmu Administrasi Negara, Universitas Negeri Padang \\ ${ }^{2}$ Jurusan Ilmu Administrasi Negara, Universitas Negeri Padang \\ a) accydeajeng@gmail.com, ${ }^{b)}$ zikrialhadi@fis.unp.ac.id
}

\begin{abstract}
This study aimed to determine the preparedness of students in facing the risk of earthquake and tsunami disasters at MTsN 1 Kota Pariaman. This study is motivated by the lack of understanding of students in dealing with disaster risks, so that there are still many students who are not ready. This study is descriptive quantitative. The population in this study were students of class vii and viii MTsN 1 Kota Pariaman in the 2018/2019 academic year, totaling 489 students. Sampling in this study amounted to 220 students with an error rate of 5\% and the sampling technique used the Random Sampling Test. The data was collected using a questionnaire with a Guttman scale measurement. The results of the study in general the readiness of students were in the very ready category, namely as many as 118 respondents or 53.6\%. This proves that there has been an increase in student preparedness
\end{abstract}

Keywords : Disaster Risk, Earthquake, Tsunami, Preparedness

Corresponding author. Email. accydeajeng@gmail.com

How to cite this article. Sudirman, K. Deajeng \& Alhadi, Z. (2020). Analisis Kesiapsiagaan Siswa dalam Menghadapi Risiko Bencana Gempa Bumi dan Tsunami. Jurnal Mahasiwa Ilmu Administrasi Publik (JMIAP) Jurusan Ilmu Administrasi Negara Fakultas Ilmu Sosial Universitas Negeri Padang, Volume 2 (3), Hal. 117-124.

http://jmiap.ppj.unp.ac.id

ISSN : 2684-818X (Online), ISSN : 2338-7378 (Print)

Copyright $\odot 2020$. Published by Labor Jurusan Ilmu Administrasi Negara FIS UNP, Padang 


\section{PENDAHULUAN}

Secara geografis, negeri gugusan pulau nan lempeng benua Asia, Australia, samudra Hindia, dan samudra Pasifik ialah Indonesia. Di selatan dan timur ada gunung berapi mengulur dari pulau Sumatera-JawaNusaTenggara-Sulawesi, yang sisinya terdiri tempo gunung berapi serta lautan. Keadaan itu sangat bahaya tragedi seperti tanah longsor, letusan gunung berapi, banjir, gempabumi dan tsunami. (UU No 27 tahun 2007). Sejarah atau catatan peristiwa gempa bumi dan tsunami di Kepulauan Indonesia sangat banyak. Salah satunya peristiwa gempa bumi di Sumatera Barat 30 September 2009 sebesar 7,6 SR dengan kerugian yang sangat besar. Banyaknya korban jiwa yang ditimbulkan akibat bencana gempa bumi, salah satunya disebabkan kurangnya pengetahuan masyarakat dalam menghadapi kondisi gempa, terlebih lagi apabila terjadi tsunami.

Peristiwa bencana alam tidak dapat diprediksi dengan pasti kapan terjadinya, tetapi dapat diupayakan menghindari jatuhnya korban jiwa melalui mitigasi. Pemerintah Kota Pariaman dan Badan Penanggulangan Bencana Daerah (BPBD) Kota Pariaman telah menyusun program yang direncanakan untuk mitigasi bencana tersebut, salah satunya adalah sosialisasi tentang kesiapsiagaan komunitas sekolah dalam mengantisipasi gempa bumi dan tsunami, khususnya sekolah-sekolah yang berlokasi di zona merah. Zona merah adalah zona awas tsunami yang berada pada ketinggian 0-5 meter di atas permukaan laut. Program ini perlu dilaksanakan mengingat banyaknya jumlah sekolah yang berada dizona merah tsunami Kota Pariaman.Pengalaman gempa Sumatera Barat menunjukkan betapa besarnya dampak kerusakan sekolah, khususnya ruangan kelas. Selain infrastruktur bangunan sekolah, tidak dapat dibayangkan apabila kejadian bencana terjadi pada jamjam sekolah.

Untuk mengurangi dampak bencana, maka dibutuhkan kesiapsiagaan ketika menghadapi gempa bumi dan tsunami.
Menurut Badan Rehabilitasi dan Rekonstruksi (2009) "kesiapsiagaan merupakan bagian serius dari aktivitas akibat tragedy yang lebih aktif sebelum tragedy terjadi". Komunitas sekolah merupakan komunitas bahaya tragedy. Menurut BNPB "mengenang banyaknya sekolah terdapat area bahaya gempabumi dan tsunami,maka kesiapsiagaan di sekolah sangat penting". Hal ini menjadikan banyaknya korban apabila tidak dikerjakan cara desklinasi akibat tragedi (BNPB,2012).

MTsN 1 Kota Pariaman merupakan salah satu sekolah yang berada dekat dengan bibir pantai Pariaman yang letaknya di Pasir Pauh Pariaman. Guru dan pegawai serta siswa MTsN 1 Kota Pariaman melaksanakan siaga bencana dalam rangka mengurangi banyaknya korban apabila akan terjadi bencana gempa dan tsunami. Ketika terjadi gempa yang kuat yang dilakukan 3 B, yakni: pertama, Berlutut.kedua, Berlindung dibawah meja sambil tangan diatas kepala kita. ketiga, Bertahan disudut dinding/segitiga tempat berpegang (Pariaman,Sitinjausumbar.com.2018).

Dimana banyak siswa yang mengalami kecemasan akan bencana karena daerah MTsN 1 Kota Pariaman merupakan daerah rawan bencana dan masih banyak siswa yang masih kurang mempersiapkan diri dalam menghadapi bencana gempa bumi. Untuk lebih paham dan terkoordinirnya cara menghadapi bencana gempa bumi dan tsunami maka dilakukannya simulasi atau pelatihan untuk meningkatkan kesiapsiagaan dalam menghadapi risiko bencana.

Berdasarkan uraian tersebut, penulis tertarik untuk meneliti mengenai "Analisis Kesiapsiagaan Siswa dalam Menghadapi Risiko Bencana Gempa Bumi dan Tsunami di MTsN 1 Kota Pariaman". Rumusan masalah yang ingin dibahas dalam riset ini adalah "Bagaimanakah kesiapsiagaan siswa dalam menghadapi risiko bencana gempa bumi dan tsunami di MTsN 1 Kota Pariaman". Berdasarkan rumusan masalah tersebut, diperoleh tujuan riset ini yaitu: Memperoleh informasi kesiapsiagaan siswa 
dalam menghadapi risiko bencana gempa bumi dan tsunami di MTsN 1 Kota Pariaman.

\section{TINJAUAN PUSTAKA}

\section{Konsep Risiko Bencana}

Menurut Badan Koordinasi Nasional Penanggulangan Bencana (2007), pada dasarnya risiko adalah suatu kapasitas keesusahan yang terjadi oleh tragedi diwilayah dan jangka waktu tertentu mengakibatkan kematian, luka, sakit, jiwa terancam, hilangnya rasa aman, kerusakan, atau kehilangan harta. Badan Nasional Penanggulangan Bencana (2015), menjelaskan kejadian bencana yang berulang memberikan dampak khusus bagi masyarakat, untuk itu perlu dilakukan penanggulangan bencana yang meliputi tahap pencegahan, dan rekontruksi baik sebelum, sesaat, dan sesudah terjadinya bencana.

Selain itu, salah satu kegiatan penanggulangan bencana yang saat ini sedang giat dilakukan pemrintah adalah pembuatan dokumen pengurangan risiko bencana diberbagai daerah, sebelum dokumen tersebut dibuatkan maka harus dilakukan analisis risiko. Analisis risiko bencana yaitu analisis potensi kerugian yang ditimbulkan oleh bencana pada suatu wilayah pada kurun waktu tertentu, dimana pemenuhaan syarat analisis risiko bencana bersumber dari dokumen yang disahkan oleh pihak yang berkompenten.

\section{Konsep Pengurangan Risiko Bencana (PRB)}

Pengurangan risiko bencana merupakan upaya pengendalian tragedi dalam suasana tidak terjadi tragedi yang dimaksudkan untuk menyusutkan efek jelek tampaknya ditimbukan akibat tragedi (Efendi, 2009). Pada siswa sekolah menengah pertama rencana PRB yang disusun sedemikian rupa bertujuan untuk :
a. Menumbuhkan
nilai
dan
sikap kemanusiaan.
b. Menumbuhkan sikap dan kepedulian.

c. Mengembangkan pemahaman mengenai risiko bencana, kerentanan sosial, kerentanan fisik, dan kerentanan prilaku dan motivasi.

d. Meningkatkan pengetahuan dan keterampilan siswa dalam pencegahan dan pengurangan risiko bencana.

e. Meningkatkan kemampuan tanggap darurat terhadap bencana pada siswa.

f. Menebarkan cara bimbingan pelatihan tentang PRB.

Substansi dasar aksi Hyogo yang diadopsi oleh Indonesia dalam pengurangan risiko bencana adalah sebagai berikut :

a. Pelaksanaan pengurangan risiko bencana harus didukung oleh kelembagaan yang kuat dengan cara meletakkan sebagai prioritas nasional maupun daerah.

b. Menandai, meninjau dan melihat risiko bencana serta menerapkan sistem peringatan dini.

c. pengetahuan, inovasi dan pendidikan dimanfaatkan sebagai pembangun kesadaran keselamatan diri dan ketahanan.

d. Meminimalisir faktor penyebab risiko bencana.

e. Memperkokoh kesiapan mengatasi bencana agar respon yang dikerjakan sangat efektif (RAN-PRB 2006-2009)

BPBD membagi Strategi Pengurangan risiko bencana menjadi tiga macam, yaitu:

a. Pencegahan. Pencegahan yaitu pengelolaan sumber bencana sehingga tidak menimbulkan risiko, muncul dengan perlakuan diharapkan perlu dicegah seperti gempabumi dan cuacaekstrim.

b. Kesiapsiagaan. Kesiapsiagaan yaitu upaya penyelamatan diri (berfokus kepada komunitas) saat terjadi bencana.

c. Mitigasi. Mitigasi, yaitu membangun penghalang (buffer) secara struktural ataupun non struktural yang mampu melindungi komunitas dari bencana yang mungkin terjadi.Secara umum mitigasi dapat dikelompokkan ke dalam 2 jenis yaitu mitigasi struktural dan non struktural. Mitigasi struktural yaitu 
berhubungan dengan usaha-usaha konstruksi fisik. Sementara mitigasi non struktural yaitu persiapan cara manfaat kapling yang cocok dengan kerentanan wilayahnya dan memberlakukan peraturan (law enforcement) pembangunan.

\section{Konsep Bencana Alam}

Menurut UNDMTP (United Nations Disaster Management Training Programme/ Program Pelatihan Manajemen Bencana PBB) (2010:10) "bencana ialah suatu provokasi yakin berkenaan guna bentuk kelompok yang mengakibatkan kematian yang melampaui kompetensi kelopok yang terdorong buat menangani dengan menggunakan sumber daya mereka sendiri”. Sedangkan menurut peraturan kepala Badan Nasional Penanggulangan Bencana (BNPB) nomor 2 tahun 2012 "kejadian melagak dan menggangu aktivitas atau pencaharian kelompok nan berdampak, bagus bagi aspek lingkungan maupun tidak lingkungan yang menyebabkan kererugian, usakan lingkungan.

Maka bisa disimpulkan bahwa bencana alam yaitu tragedi nan mendatangkan bagi seuntai kejadian bagi lingkungan diantaranya gempabumi dan tsunami. Dimana menurut Direktorat Vulkanologi dan Mitigasi Bencana Geologi, Departemen Energi dan Sumber Daya Mineral "gempabumi yaitu berguncangan diakibatkan adanya benturan, patahan aktifativitas berapi". Sedangkan menurut triatmadja (2010:1) "tsunami merupakan arus berjarak karena aksi dasar laut berupa patahan". Pengetahuan tentang kebencanaan memegang peranan penting dalam proses penyelamatan diri saat terjadinya bencana. Pemahaman yang baik tentang bencana akan berdampak baik. Berikut cara penyelamatan diri terhadap gempabumi serta tsunami,

a. Gempa Bumi

1) Bersembunyi, lindungi kepala dan bertahan ditempat aman! Beranjak menjauh dari jendela
2) Jika berada di tempat tidur, ambil bantal dan Lindungilah kepala

3) cari tempat aman yang jauh dari kemungkinan ambruknya bangunan, pohon, dan kabel.

4) Jika berada di dalam mobil, kemudikan mobil menuju tempat aman dengan hati-hati. Keluar dari kendaraan dan kerjakan evakuasi.

5) Selesai gempa berhenti, karena kemungkinan terjadinya gempa susulan maka jangan lah masuk ke dalam bangunan dengan segera

b. Tsunami

1) Bersiaplah kemungkinan pesan darurat tsunami selesai terjadinya gempa bumi.

2) Jangan berada di pantai setelah merasakan gempa bumi. Segera berlari ke tempat yang aman

3) Gedung berlenggek yang tingginya lebih dua lenggek yang berjarak lebih dari $500 \mathrm{~m}$ garis pantai

\section{Konsep Kesiapsiagaan}

Berdasarkan BNPB no 2 thn 2012 kesiapsiagan ialah guna meredakan dan meluak tragedi untuk penanggulangan dengan berbagai aktivitas yang dilakukan. Kesiapsiagaan dilaksukan guna menangkal kesempatan tragedy untuk menjauhi sasaran. Sehubungan dengan itu, UNISDR (2006:5) menyatakan: "Kesiapsiagaan adalah pemahaman dan kinerja bagi pemrintah, badaan ahli waris paham gawat serta penyembuhan sehabis tragedy, kelompok serta perseorangan bagi insiden ancaman maupun keadaan nan bisa berlangsung".

Maka disimpulkan kesiapsiagaan ialah kesiapan seluruh lapisan masyarakat akan saat terjadinya, dan tindakan pemulihan setelah terjadinya bencana. Kesiapsiagaan suatu komunitas dapat dpengaruhi oleh faktor-faktor tertentu. Menurut LIPIUNESCO/ISDR (2006) "yang dapat mempengaruhi kesiapsiagaan antara lain adalah: keadaan jasmani serta bentuk kemasyarakatan adat, dan lain-lain”. 


\section{METODE PENELITIAN}

Jenis riset yang dikerjakan ialah riset analisis deskriptif. Analisis deskriptif adalah suatu cara untuk memperoleh dan menafsirkan data sehingga memberikan gambaran yang jelas melalui pengumpulan data, penyusunan data, dan penganalisaan data. Lokasi penelitian ini dilakukan di sekolah MTsN 1 Kota Pariaman, karena sekolah tersebut rentan terhadap bencana alam dan berada dizona merah kota pariaman dekat dengan bibir pantai pariaman.

Populasi dalam penelitian ini adalah siswa kelas vii dan viii MTsN 1 Kota Pariaman tahun ajaran 2018/2019 yang sebanyak 489 siswa. Penarikan sampel dalam riset ini sebanyak 220 siswa dengan tingkat kesalahan 5\% dan teknik $U j i$ Random Sampling untuk sampel yang diambil. Pengumpulan data dilakukan dengan menggunakan angket dengan pengukuran skala Guttman.

\section{HASIL DAN PEMBAHASAN}

Karakteristik Responden

Dalam penelitian ini jumlah responden sebanyak 220 siwa di MTsN 1 Kota Pariaman disajikan dalam diagram berikut ini:

\section{Gambar 1. Berdasarkan Usia}

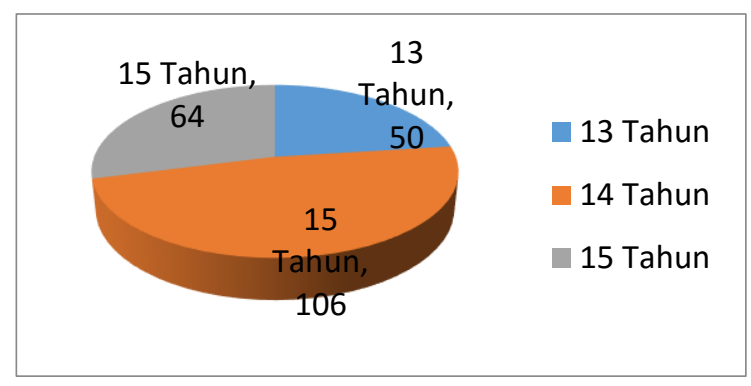

Berdasarkan grafik diatas dapat dilihat bahwa karakteristik berdasarkan usia responden terdiri dari 3 jenis yaitu usia 13 tahun sebesar $22,7 \%$, usia 14 tahun sebesar $48,2 \%$ dan usia 15 tahun sebesar $29,1 \%$.

Hasil penelitian ini menunjukkan bahwa sebagian besar responden berada pada usia 14 tahun, yaitu sebanyak 106 responden atau 48,2\% (remaja pertengahan). Hurlock (2011) menyatakan klasifikasi usia remaja pertengaan adalah 14-16 tahun. Hasil penelitian ini sejalan dengan penelitian yang di lakukan Salasa, dkk. (2017) di Kecamatan Semarang tentang pemberdayaan pada kelompok remaja melalui pendekatan contingency planning dalam meningkatkan kesiapsiagaan terhadap ancaman kematian akibat bencana menyebutkan bahwa kelompok remaja merupakan usia potensial dibandingkan pada usia lainnya dan sangat baik untuk meningkatkan kesiapsiagaan terhadap ancaman kematian sehingga dapat melakukan pendampingan terhadap kelompok rentan.

Hasil penelitian ini menggambarkan kesesuaian dengan teori bahwa pada usia remaja individu akan lebih berperan aktif dalam masyarakat dan kehidupan sosial serta lebih banyak melakukan persiapan untuk menghadapi suatu kejadian-kejadian yang akan datang secara tiba-tiba.

\section{Gambar 2. Berdasarkan Jenis Kelamin}

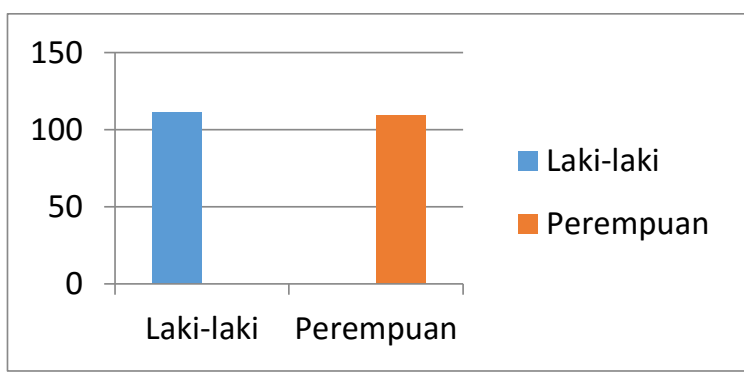

Dapat dilihat bahwasanya besar jumlah respoonden yang berhenis kelamin laki-laki dan perempuan dalam penelitian ini hampir seimbang yaitu dengan presentase laki-laki sebesar 50,5\%, sedangkan persentase perempuan sebesar 49,5\%.

Hasil penelitian menunjukan bahwa sebagian besar responden berjenis kelamin laki-laki yaitu sebanyak 111 responden $(50,5 \%)$. Dalam proses pembelajaran, terdapat beberapa perbedaan karakteristik remaja dilihat dari jenis kelamin. Anak perempuan mempunyai sifat yang lebih tenang dan emosi cendrung lebih stabil, sehingga dalam hal pengetahuan anak perempuan lebih unggul dibanding anak laki-laki. Namun dalam hal keterampilan 
dan gerakan motorik kasar anak laki-laki cenderung lebih aktif dan agresif dari anak perempuan, hal ini memungkinkan anak laki-laki lebih mudah gelisah dan bergerak dengan cepat jika terjadi suatu ancaman (Sugihartono, dkk, 2013).

\section{Hasil Pengolahan Data}

Berdasarkan hasil pengolahan data yang telah dilakukan tentang kesiapsiagaan siswa dapat digambarkan dalam diagram berikut ini

\section{Gambar 3. Kesiapsiagaan Siswa}

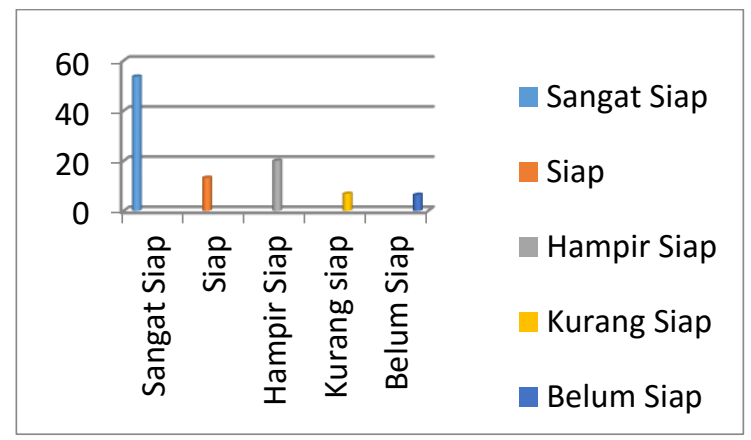

Berdasarkan grafik tersebut dapat diketahui bahwa persentase kesiapsiagaan siswa pada kategori sangat siap sebesar $53,6 \%$, pada kategori siap sebesar $13,2 \%$, pada kategori hampir siap sebesar 20,0\%, pada kategori kurang siap sebesar $6,8 \%$ dan pada kategori belum siap sebesar $6,4 \%$. Sehingga dapat disimpulkan bahwa pada umumnya tingkat kesiapsiagaan siswa berada pada kategori sangat siap yaitu sebesar 53,6\%.

Kesiapsiagaan terhadap bencana diukur berdasarkan paremeter: pengetahuan dan sikap, rencana tanggap darurat, sistem peringatan bencana, dan mobilisasi sumber daya.

a) Pengetahuan siswa MTsN 1 Kota Pariaman tentang bencana gempa bumi dan tsunami. Hal ini menggambarkan masih terdapat siswa yang belum mengetahui tentang bencana gempa bumi dan tsunami. Diketahui bahwa pengetahuan seseorang tentang kebencanaan dapat berakibat pada sikap dalam menghadapi bencana itu sendiri. Sebagaimana yang dikemukakan oleh
LIPI-UNESCO (2006:14) bahwa pengetahuan terhadap bencana merupakan alasan utama seseorang untuk melakukan kegiatan perlindungan atau upaya kesiapsiagaan yang ada. Pengetahuan yang dimiliki mempengaruhi sikap dan kepedulian siswa untuk siap dan siaga dalam mengantisipasi bencana, terutama bagi mereka yang bertempat tinggal di daerah yang rentan terhadap bencana alam. Tingginya pengetahuan siswa tentang bencana gempa bumi dan tsunami disebabkan oleh berbagai factor, diantaranya sudah terdapat buku bacaan tentang bencana alam diperpustakaan sekolah, kemudian didukung oleh kemajuan teknologi yang dimanfaatkan oleh kebanyakan siswa dalam mengakses materi tentang kebencanaan melalui internet, serta pemberian materi kebencanaan oleh guru kepada siswa dalam proses belajar mengajar, dan dikarenakan juga adanya pemberian simulasi siaga bencana.

b) Kesiapsiagaan siswa MTsN 1 Kota Pariaman terkait tanggap darurat bencana. Hal ini menggambarkan masih terdapat siswa yang belum mengetahui tentang bencana gempa bumi dan tsunami. Diketahui bahwa seharusnya dilakukan sebelum dan saat terjadinya bencana gempa bumi dan tsunami. Berdasarkan Peraturan Kepala BNPB nomor 10 tahun 2008 tentang pedoman komando tanggap darurat bencana, "tanggap darurat bencana adalah serangkaian kegiatan yang dilakukan dengan segera pada saat kejadian bencana untuk menangani dampak buruk yang ditimbulkan". Rencana tamggap darurat menjadi bagian yang penting dalam suatu proses kesiapsiagaan, terutama yang terkait dengan evakuasi, pertolongan, dan penyelamatan agar korban bencana dapat diminimalkan. Pengetahuan tentang tanggap darurat bencana tergolong tingggi dikarenakan sudah efektifnya pelaksanaan pemberian 
simulasi siaga bencana kepada para siswa. Kemudian bahan bacaan siswa terkait tanggap darurat bencana, baik cetak maupun elektronik. Hal ini juga, merupakan manfaat dari kegiatan penyuluhan dan simulasi di MTsN 1 Kota Pariaman. Timgginya pemahaman siswa terkait upaya yang harus dilakukan saat terjadinya bencana diharapkan dapat meminimalisir jatuhnya korban. Mengingat banyak jatuhnya korban anak sekolah pada bencana gempa bumi tahun 2009 silam dikarenakan tidak mengetahui tindakan tepat yang harus dilakukan saat tejadinya bencana.

c) Kesiapsiagaan siswa MTsN 1 Kota Pariaman terkait pengetahuan tentang sistem peringatan dini tsunami. Terlihat masih terdapatnya siswa yang belum mengetahui tentang peringatan dini tsunami. Diketahui bahwa pengetahuan tentang sistem peringatan dini tsunami akan mempengaruhi kesiapan individu dalam mengenal tanda-tanda terjadinya bencana tsunami. Menurut LIPIUNESCO/ISDR (2006:14), "peringatan dini sebagai bagian dari pengurangan risiko bencana tidak hanya mengenai peringatan yang akurat secara tekni, tetapi juga harus membangun pemahaman risiko yang baik dari suatu peringatan". Sistem yang baik adalah sistem dimana masyarakat juga mengerti informasi yang akan diberikan oleh tanda peringatan dini tersebut atau tahu apa yang harus dilaakukan jika suatu saat tanda peringatan dini bencana berbunyi/menyala. Sistem peringatan meliputi tanda peringatan dan distribusi informasi jika akan terjadi bencana. Pemahaman tentang peringatan dini yang baik dapat mengurangi kerusakan yang dialami oleh masyarakat, terutama meminimalisir jatuhnya korban jiwa akibat bencana tsunami.

\section{PENUTUP}

Berdasarkan hasil penelitian yang telah dilaksanakan tentang analisis kesiapsiagaan siswa dalam menghadapi risiko bencana dapat disimpulkan bahwa secara umum kesiapan mahasiswa berada pada kategori sangat siap. Hal ini membuktikan bahwa telah terjadi peningkatan kesiapsiagaan siswa, dimana sebagian besar siswa sudah berada pada kategori sangat siap.

\section{DAFTAR KEPUSTAKAAN}

Anonim. 2012. Peraturan Kepala Badan Nasional Penanggulangan Bencana (BNPB) nomor 2 tahun 2012 tentang Pedoman Umum Pengkajian Risiko Bencana.

2007. Undang-Undang Republik Indonesia nomor 27 tahun 2007 tentang Pengelolaan Wilayah Pesisir dan Pulau-Pulau Kecil.

2008. Peraturan Kepala Badan Nasional Penanggulangan Bencana (BNPB) nomor 4 tahun 2008 tentang Pedoman Penyusunan Rencana Penanggulangan Bencana.

Ari.13 Oktober 2018. (Review) Simulasi Siaga Bencana di MTsN 1 Kota Pariaman.http://sitinjausumbar.com/be rita/detail/simulasi-siaga-bencana-dimtsn-1-kota-pariaman.

\section{LIPI-UNESCO/ISDR.2006.Kajian}

Kesiapsiagaan Masyarakat dalam Mengantisipasi Bencana Gempa Bumi dan Tsunami.

Prager, Ellen J. 2009. Furious Earth (TheodorusWibisono.Terjemahan).

Newyork: Miles Kelly. Buku asli diterbitkan tahun 2006.

Sanjaya, W. (2013). Strategi Pembelajaran: Berorientasi Standar Proses Pendidikan.

Suhardjo, D. (2011). Arti Penting 
Kessy Deajeng Sudirman, Zikri Alhadi I Analisis Kesiapsiagaan Siswa dalam Menghadapi Risiko Bencana Gempa Bumi dan Tsunami

Pendidikan Mitigasi Bencana Dalam

Mengurangi Resiko Bencana.

Cakrawala Pendidikan, Juni, Th. XXX,

2.

Triamadja, Radianta. 2010. Tsunami.

Yogyakarta: Gadjah Mada University Press.

United Nations Disaster Management Training Programme (UNDMTP). 2012. Pelantikan untuk Pelatih mengenai Standar-standar Minimum untuk Pendidikan dalam Situasi Darurat. Bandung 